中凹なためこの部分の逃げが足りない。第 4 図はこれをシ ンニングしたもので上の久点が除かれてるる。第 5 図は直

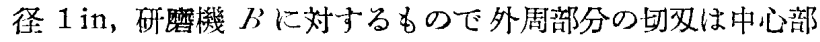
分と変つた角度に面を取られる。次に第 6 図に種々の直径の 踓に就き、牛怿に対する 逃げ角の変化变一括した。図中 $A$


研蘑: 機 $B$

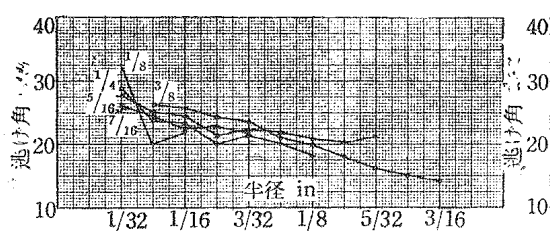

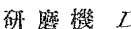

研磨 維 $E$

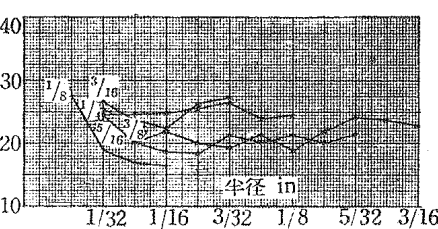

第 6 図

はこれが一様で直待によりあ屯り変らないが $D$ は稍差が多 くEは可成り激しい。これは䤠の取付方法に欠点があるた めと思はれる。 $B$ は㨁待 1 in の䬺では良いが小さい錐では 差が可成りある。

著者は次いで錐もみ試驗も行ひ成績を比較したがトルク、 スラスト共に何れの研磨機によるも大差はない。只 $B$ の様 に外周部分の面を取つた䤵では孔の寸法公差、仕上が他に勝 り寿命も滛に長い。一例挙げると、錐の直径 $3 / 8$ in, 孔の 深さ 1 in, 工作物 SAE 6150 (ロックウェル 硬度 $B$ 92) に 対し削り速度 $166 \mathrm{ft} / \mathrm{mn}$, 揆り $0.0085 \mathrm{in} / \mathrm{rev}$ で确耗末での 穿孔数の研磨機によるものでは 2〜5 なるに対し $B$ による ものは 11 個の後份充分の切味を保つてるる。勿論これは面 取りそのものによる效果で他の研磨した鑊でも後で面を取れ ば同様な成績を示す。

(永瀨)

\section{[137] カーパイドカッタの研磨}

[H. Ernst, M. Kronenberg, Mech. Lngg.*, 1937-4, Vol. 59, No. 4, 頁 221 226, 図 9, 表 3] 高速度鋼のブリネ 儿硬度 650 程度に対しカーバイド昒材 のそれは 1500 1800 一遙に高く又脆さも大きいため研磨にも特別な注意が 要る。著者は 植为ッタの研磨に就しの注意事項を述べた。

1. 砥石車 ${ }^{(\mathbf{1})}$ 砥石の見掛上.の硬さはその実際の硬さと速 度による。速度が高い程大きい。故に速度を一定に保つ必要 があるが砥石車の磨耗は カーバイドに対して極めて早いの で丸形䂠石車ではこれが困難である。栁形砥石車ではこ0、次 点はないが接触が本面で起る。これに上る不利を除くには䂠 石車の側面に勾配を付けるか又は粗い質の軟い物を用ひる。 車の直径は 3.5 -5 in，速度は 3500 ～5000 ft $/ \mathrm{mn}$ であるが 発熱を減じ仕上を良くするため低い速度を使ふ傾向がある。

(1)この砥石車は abrasive wheel を指し、がイヤモンド車に対する ものである。以下同じ。
又欢物が硬い程砥石は細かく軟くせ奴ばならぬがその理論的 根拪は未だ研究されてるない。冷却液を使ふか否かは人によ り意見を異にするが何れにせ上少量の使用は禁物である。併 し多量の液は観察上作業上不便を與へるため漸次液は用ひら れなくなりつ〉ある。第 1 表は カーボランダム、ノルトン 闭社の砥石車選択芘である。

2. ダイヤモンド車 カーバイド双物の寿命は切 來の銳さと面の滑さによること大であるため従未研 磨後 ラップ磨きが行はれた。ダイヤモンド車は これに一步を淮めたもので、カーボンンダム社製品 は等級郎ち含有率 $A B C$ ，粒度 $100,130 ， 240 ， 400$, フルト二社製品は粒度粗削り用 100 , 仕上用 220 及 び 400, 两用 150 である。目值しは特殊の砥石棒を 用ひ低速で行ふ。ダイヤモンドを使ふのは不経済 である。偏心は 取付ナットを一寸弛め手で叨いて 直し、栁形車の側面は軸から外し研磨剮を與へ䤻鉄 板上で擦つて直す。冷却液は一般に油で第 1 図の 様にフェルトにより量を加減し速度は砥石車より

第 1 表 砥石車選択表

\begin{tabular}{|c|c|c|c|c|c|}
\hline & カーボランダム证 & \multicolumn{4}{|c|}{ ノルトン佂 } \\
\hline 莣 研 磨 & $\begin{array}{c}60 \mathrm{~S}-\mathrm{WHG} \text { (種類 } \\
60 \sim 80, \mathrm{R}-\mathrm{T} .)\end{array}$ & $\begin{cases}3 & 760 / 1-\mathrm{J} 7 \\
3 & 760 / 1-\mathrm{I} 7\end{cases}$ & & 却液 & $\begin{array}{l}\text { (不用) } \\
\text { 使用) }\end{array}$ \\
\hline 仕上研磨 & $\begin{array}{c}120 \mathrm{U}-\mathrm{WIG} \text { (種類 } \\
100 \sim 120, \mathrm{~s} \sim \mathrm{V} .)\end{array}$ & $\begin{cases}37 & 100-\mathrm{H} 7 \\
37 & 100-17\end{cases}$ & & "I & $\begin{array}{l}\text { 不用) } \\
\text { 使用) }\end{array}$ \\
\hline 箫 両 用 & & $\begin{cases}3 & 780 / 1-\mathrm{I} 7 \\
3 & 780 / 1-\mathrm{J} 7\end{cases}$ & ( & $" \prime$ & $\begin{array}{l}\text { 不用) } \\
\text { 使用) }\end{array}$ \\
\hline
\end{tabular}

$50 \%$ 高くする。図の研硡機はこのため 2 段調車を有する。 第 2 図は砥石車との成績比較であるが優劣は一目して明かで あら5。份車の清掃には軽石を用ひる。

3. 切多の形狀々角度 カッ夕の形狀々削り角標蕉は各国 共出来てるない。第 3 図及び第 2 表はシンシナチ社推獎の もので図中右下の形は主切双が二つあるため左上の一つのも のに対し研磨が面倒で切剀中矞が湿乱し易いが合廣く使はれ てるる。又図に示す様に逃げは第 1 次の逃げ郎ち線、及び第 2 次の逃げの 2 段ある。これは第 1 次逃げ角を少くすること に上り及の强さと熱傳導力を增し而も第 2 次逃げ角により背



第 1 図フェルト布片による冷却油供給

[第 40 卷 第 245 号 

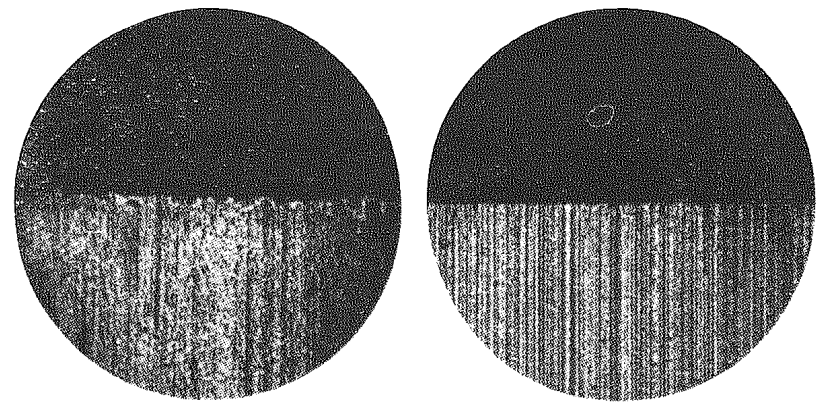

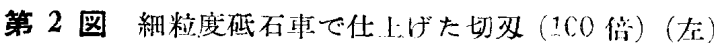
細粒度ダィヤモンド車で仕上げた切为（100 倍）(右)
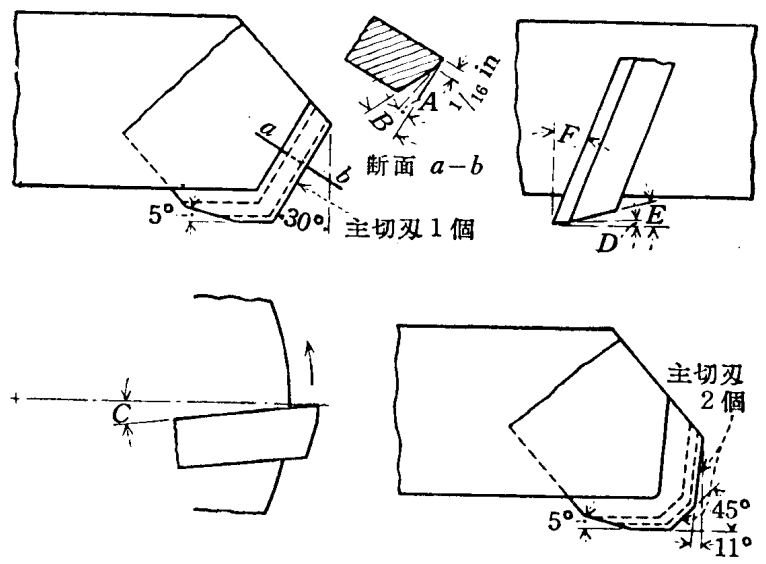

第 3 图切皮の形 爿

第 2 表 制り 角表

\begin{tabular}{lr|r|r|r|r|r|r}
\hline 角 (第 4 図) & $A$ & $B$ & $C$ & $I$ & $E$ & $F$ \\
\hline 鋳 & 鉄 & 4 & 8 & 5 & 3 & 6 & 3 \\
アル ミニウム & 8 & 12 & 30 & 4 & 8 & 30 \\
\hline
\end{tabular}

面の摩擦を防ぎ、又矿想の際車々鋼の植及こ触れて及先の仕 上を害することのない様にする伛めである。勿論数回の砥ぎ 直しでこの緣が廣くなれげ又第 2 次の逃げ部分も砥ぎ直さね ばならない。

4. 研磨の実際 最も高い双と低い汉の差は 000005 in 以 下に收める必要があり、砥不車に対してはダイヤルゲーヂ 又は第4図の様な特殊な目直し裝置を用ひ秝ばならないが、 ダイヤモント車には斯様な必要はなく只特異な硬い音と火 花の消隇之を以て目標之すれば充分で、佮 減摩䅛動テーブル 裝置付き新式研想機に熟練せる作業者は揆りハンドル車の 重さで砥ぎトりが知れる。䢪りは手䢪りの方が無理が無くて 这い。取り代は 1 回 0.0002 in 以下とし車の回轉方向は切㸚 から後に向く様にする。又部分的過熱を防ぐため切外は絕え ず動かす必要がある。磨耗の甚しい時は砥石車で荒砥ぎして から粒度 100 及び 400 のダイヤモンド車でップ磨きす る。普通の想耗に対しては粒度 100 , 中級のダイヤモンド車 で優に粒度 120 の仕上用硴石車に勝る仕けが得られ特に仕上 を要しない。切炏は余り䐴耗せ奴中砥ぎ直すのが良い。実驗 によると鋳鉄のフライス削りに於て必の磨耗が後に0.008 〜0.010 in の巾になると急に面の仕上が腎く成り为の㬗耗も 早くなることが知られた。

昭和 12 年 9 月了



第 4 图砥石車目㨁し装置

佮 カッ夕の成績を上げるには前述の様な研磨上の注意と 共にボディへの植取付法、ボディ 自身の剛さと精度が大 切な要素である。

（永瀨）

\section{［138］如何にして加工時間を正しく 推定すべきか}

[E. Bramesfeld, W. Schener, Der Betrieb., 1937-5, Bd. 16, Ht. 9 10, 頁 237〜239, 図 1, 表1] 精確な加工特間 を知るには時間調查によるのが正統な方法であるが、加工個 数の少い場合或は咄菱の聞には一々これを行ふことは出未な い。この様な場合には推定によつて出来るだけ正しい加工時 間を求めることが必要となつにくる。加工時間の推定に就て 次の項目をあげることが出来る。

1. 時間推定をこのため訓練した人々が資料 (装、標淮值) なしで行つた場合の正確度はどの程度であるか。

2. 時間推定に関する心理過程如何

3. 時間推定を実際に如何にして行ふか、又時間計算人及 び時間調查人の選定及び訓練を如何にすべきか。

第 1 の問題に就て次の 3 種類の実驗を行つた。

符 1 実驗 曲り金の製作に対する時間推定

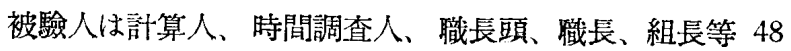
人であり、これら被驗人に第1図に示す様な曲り金の図面と 試問用紙を與へて試驗を行つた。加工法は鋸挽き、釬掛け、 孔あけ及びね机によるものと定めいある。時間推定は全 体を一度に推定する方法、加工法を大きく分割してなす方法 及び細に (16 階程) 分ける力法の 3 種によつて行つた。

この結果は第 1 図に示す如くである。推定時間は最大 180 $\mathrm{mn}$, 最小 $4.2 \mathrm{mn}$ で、その美異は実に 45 倍に達してるる。 然るにこの代事を数人の熟練丁によつて実際に行つた結果の 平均は $10 \mathrm{mn}$ となつた。(第1図 $a$ )この結果によれば 10\% 以内の誤差によつて答へた人は僅に 3 人郎ち $6 \%$ に過ぎない。 倘加工過程を大きく分けた場合及び細く分けた場合に於て も推定結果に大した差のないことは注目に值する。

又時間を過大に推定した人は 42 人 $=88 \%$, 過小に推定し た人は4人である。

第 2 実驗

導線を仕梯書によつて連結する仕事時間の推定 